\title{
Effect of Processed Lemon Pulp with Saccharomyces cerevisiae in Zaribi Goats Diet on Milk Production, Nutrients Digestibility, Blood Parameters, and Reproductive Performance
}

\author{
Haiam Abd Elsalam Sayed*, Mahmoud MetwalyEl-Maghraby, and Mohamed Mahmoud Elbadawy \\ Animal Production Research Institute, Ministry of Agriculture, Dokki, Giza-12618, Egypt \\ *Corresponding author's Email: haes1979@yahoo.com; (D) ORCiD: 0000-0002-4746-5134
}

\begin{abstract}
The aim of the present study was to evaluate the effect of replacing concentrate feed (CFM) mixture with different levels of treated lemon pulp (TLP) on milk production and composition, nutrients digestibility, and blood parameters of Zaribi goats. A total of 24 Zaribi female goats at the end of the pregnant period were divided into three groups of eight according to live weight. Concentrate feed mixture and clover hay at a rate of 50:50 were offered twice a day. Treatedlemon pulp replaced CFM at rates $0 \%, 25 \%$, and $50 \%$ in diets of R1, R2, and R3 treatment groups, respectively. The feeding trial lasted 90 days. Dry matter digestibility and Nitrogen free extract digestibility were significantly raised by the increased level of TLP in groups R2 (72.37\% and 70.36\%) and R3 (72.28\% and 70.30\%), compared to $(70.99 \%$ and $68.51 \%)$ in R1, respectively. The same trend was observed for organic matter digestibility (OMD), crude protein digestibility (CPD), crude fiber digestibility (CFD), and ether extract digestibility (EED) with R3, compared with either R1 or R2. However, there were insignificant differences between R1 and R2 in terms of $\mathrm{OMD}$, CPD, and EED but CFD was significantly higher in R2, compared to R1. There was a significant increase in the milk yield by the increased level of TLP in the diet and for R2 $(1448.4 \mathrm{~g} / \mathrm{h} / \mathrm{d})$ and $\mathrm{R} 3(1558.7 \mathrm{~g} / \mathrm{h} / \mathrm{d})$, while it was reported as $1377.6 \mathrm{~g} / \mathrm{h} / \mathrm{d}$ in the control group. Feeding dams on the R3 diet had a significant effect on improving total antioxidant capacity by $63.5 \%$, compared with control. The results of the present study indicated that the replacement of CFM by TLP decreased the costs of feed and increase milk production for the replacement level by $50 \%$ (R3). Moreover, no adverse effects were noticed on nutrient digestibility and blood parameters of the investigated samples.
\end{abstract}

Keywords: Blood parameters, Lemon pulp, Milk production, Saccharomyces cerevisiae

\section{INTRODUCTION}

Traditional feedstuffs are very expensive so the use of agro-industrial by-products in animals' diets has been introduced as the best way to decrease the cost of the feed. In Egypt, there is a shortage of animal feeds which had a negative effect on increasing animal production. Ruminant animals can depend on by-product feedstuffs (BPF) in their diets because the rumen microorganisms can use BPF which contains high levels of crude fiber and low protein content to cover their requirements for growth, reproduction, and production.

Adding citrus by-products to ruminants' diet is suitable because the rumen microorganism has the ability to ferment high fiber feeds (Grasser et al.,1995). The citrus residues of the juice industry (oranges, tangerines, lemons, or grapefruits) are called the citrus pulp. The citrus pulp can be used in animal feeding either fresh or after ensilage or dehydration. The nutritional value of citrus pulp is high owing to its high content of readily fermentable carbohydrates and contains a variety of energy substrates for ruminal microbes (Habeeb et al., 2017). The high content of easily fermentable carbohydrates and different energy sources found in the citrus pulp which are available for ruminal microorganisms can increase its nutritional value (Habeeb et al., 2017).

This important bioprocess is characterized by microbial growth in the insoluble substrate, in the presence of small amounts of free fluid, using the nutrients and residual elements present in these residues (Pinto et al., 2005). The microbial growth in this insoluble substrate, which contains small amounts of free fluid, depends on residual elements (Pinto et al., 2005). Micro-fungi solid substrate fermentation of this pulp could increase the protein content, antioxidant activity, and digestibility of the pulp. In fact, the citrus pulp is an energy source for rumen micro-organisms.

Protein enrichment of these by-products by microorganisms improves the nutritional value of the forage palm for ruminants (Vendruscolo et al., 2009). Residues of fruits and vegetables have been good substrate for protein enrichment and bioconversion into value adds products as enzymes and other metabolites. Using Saccharomyces cerevisiae (S. Cerevisiae) and fungi to bioconvert these agro-industrial by-products in raising their protein content. Fermented pineapple wastes by S. cerevisiae for 48 hours caused an increase in protein from $6.4 \%$ to $16.1 \%$ (Roberta et al., 2007). 
Improving protein content by processing wet citrus pulp increases their efficiency in livestock nutrition. Some studies indicated that processing citrus pulp with microorganisms increases the crude protein contents as a result of converting lignocelluloses and easily-digestible materials into energy, protein, and $\mathrm{CO} 2$ by their extracellular enzymes (Scerra et al., 1999). Using pectin, digestible fiber, and soluble carbohydrates, which are found in citrus pulp residues, as a source of energy are easily and extensively degraded instead of starch led to producing acetic acid, which does not cause a pH drop like lactic acid and result in acidosis. Long rumination period and high fiber content cause large quantities of saliva buffering rumen ph. Lemon pulp is considered as a safer feed than cereals for animals fed lowroughage and high-concentrate diets in high-yielding dairy cows (Crawshaw, 2004). So, the use of agro-industrial byproducts in ruminant diets might be an alternative to replace food energy and protein concentrates, increasing the efficiency and reducing the economic costs of the production system and consequently, making it more competitive. Also, the citrus family (Citrus lemon) contains an antioxidant component. The antioxidant activity of phenolic compounds such as flavonoids and phenols in lemons can improve in reducing the risk of cardiovascular disease (Ghasemi et al., 2009).

The objective of this study was to evaluate the impact of partial replacing of CFM by lemon pulp fermented with $S$. Cerevisiae on chemical composition, digestion coefficients, blood parameters, and milk production performance of the Zaribi goats.

\section{MATERIALS AND METHODS}

This experiment was carried out at Sakha, Animal Production Research Station of Animal Production Research Institute, Agriculture Research Center during the summer season of 2020.

\section{Ethical approval}

This study was approved by the Scientific Committee of Animal Production Research Institute (protocol no: 1-22-924).

\section{Preparing lemon pulp}

Lemon pulps were collected from the Elmarowa factory in Sixth of October City, Egypt, and sun-dried for 7 days, then, the dried lemon pulp was mixed with water at 1:2 ratio (pulp: water). Then, temperature, humidity, and acidity of lemon pulp were adjusted to be suitable for yeast growth, whereas the optimal humidity and $\mathrm{pH}$ for yeast growth are $85 \%$ and 5.6, respectively, according to Dadvar et al. (2015), so, bicarbonate was added by $6.4 \%$ to the media to adjust the $\mathrm{pH}$. Samples of prepared lemon pulp were put in polyethylene bags and inoculated with $4 \%$ yeast and incubated at $35^{\circ} \mathrm{C}$ for 24 hours. After the incubation period, the samples were sun-dried for 4 days, then, kept for chemical analysis. Feed ingredients, S. cerevisiae powder, Concentrate Feed Mixture (CFM), Clover Hay (CH), and feces were analyzed for proximate analysis according to AOAC (1995) whereas Nitrogen Free Extract (NFE) was calculated by difference.

Table 1. Chemical composition of untreated lemon pulp and treated lemon pulp on dry matter basis

\begin{tabular}{lccccccc}
\hline Items (\%) & DM & OM & CF & CP & EE & NFE & ASH \\
\hline ULP & 90.98 & 91.22 & 13.59 & 8.90 & 5.03 & 63.70 & 8.78 \\
TLP & 89.80 & 87.68 & 10.86 & 13.92 & 3.46 & 59.44 & 12.32 \\
Relative change & -1.3 & -3.9 & -20.1 & +56.4 & -31.2 & -6.69 & +40.3 \\
\hline
\end{tabular}

DM: Dry matter, OM: Organic matter, CF: Crud fiber, CP: Crud protein, EE: Ether extract, NFE: Nitrogen free extract, ASH: Ash, ULP: Untreated
lemon pulp, TLP: Treated lemon pulp

\section{Experimental diets and animals}

A total of 24 Zaribi female goats at the end of the pregnant period were divided into three groups of eight according to live weight for 90 days trial. Goats in each group were fed CFM consisting of $35 \%$ decorticated cottonseed cake, $25 \%$ corn grain, $30 \%$ wheat bran, $5 \%$ molasses, $2 \%$ limestone, $1.5 \%$ salt, and mineral, and $1.5 \%$ vitamins mixture, clover hay, $\mathrm{CH}$, and treated lemon pulp (TLP). Feed was offered twice a day at 8 am and $4 \mathrm{pm}$ and the remaining amounts from the previous day were measured. Water is offered freely all day round. The CFM is adjusted biweekly according to the body weight changes and milk production. Daily feed intakes, milk production, were recorded and feed efficiency ( $\mathrm{g}$ feed/g milk) was calculated. Kids weighed biweekly before morning feeding. According to live body weight and milk production goats were fed the experimental diets as $50 \% \mathrm{CFM}$ and 50\% clover hay.

The efficiency of dams was measured by litter weight at birth, which was calculated by total kids birth weight per dam. Litter weight at weaning was measured by total kids weight at weaning per dam, and total litter weight gain was estimated by total kids birth weight minus total kids weight at weaning per dam. Finally, the average daily gain was 
calculated by the differences between total kids birthweight per dam and total kids weight at weaning divided on suckling period. On the other hand, the first group (control, R1) received experimental diets while, (R2) and (R3) experimental groups received the experimental diets by replacing $25 \%$ and $50 \%$ of CFM with treated lemon pulp, respectively. The chemical composition of raw materials and different experimental diets are presented in Table 2.

Table 2. Chemical composition of concentrate feed mixture, clover hay, treated lemon pulp, and experimental diets on a dry matter basis.

\begin{tabular}{lccccccc}
\hline Parameters (\%) & DM & OM & CF & CP & EE & NFE & ASH \\
\hline Tested materials & & & & & & & \\
CH & 89.93 & 87.59 & 25.22 & 12.80 & 2.57 & 47.00 & 12.41 \\
CFM & 91.53 & 89.97 & 11.62 & 14.02 & 2.96 & 61.37 & 10.03 \\
TLP & 90.98 & 87.68 & 13.59 & 13.92 & 3.46 & 56.71 & 12.32 \\
\hline Experimental diets & & & & & & \\
R1(control) & 90.73 & 88.78 & 18.42 & 13.41 & 2.77 & 54.19 & 11.22 \\
R2 & 90.66 & 88.50 & 18.67 & 13.40 & 2.83 & 53.6 & 11.50 \\
R3 & 90.60 & 88.21 & 18.91 & 13.39 & 2.89 & 53.02 & 11.79 \\
\hline
\end{tabular}

DM: Dry matter, OM: Organic matter, CF: Crud fiber, CP: Crud protein, EE: Ether extract, NFE: Nitrogen free extract, ASH: Ash, TLP: Treraterd lemon pulp, CFM: Concentrate feed mixture, $\mathrm{CH}$ : Clover Hay, R1: Control diet (50\%concentrate feed mixture+ 50\% clover hay), R2:37.5\% concentrate feed mixture $+50 \%$ clover hay $+12.5 \%$ treated lemon pulp, R3:25\% concentrate feed mixture $+50 \%$ clover hay $+25 \%$ treated lemon pulp.

\section{Digestibility trials}

Three animals from each group were used in digestibility trials using the acid insoluble ash (AIA) technique as an internal marker according to Van-Keulen and Young (1977) to determine the nutrients digestibility and feeding values of the experimental diets. Fecal samples of nearly $100 \mathrm{~g}$ were taken from the rectum twice daily at 8 a.m and 6 p.m for 3 days collection period. Representative samples of feed and feces from the whole collection period were prepared for proximate analysis according to AOAC (1995).

\section{Blood and milk sample analyses}

The blood samples were taken at the end of the termination of the experiment from the jugular vein in dry clean glasses tubes. Blood samples were collected into sterile blood tubes and immediately placed on ice before centrifuging to obtain serum. The serum was immediately frozen for subsequent biochemical analysis. Blood parameters, including total protein, urea-N, triglycerides, cholesterol, high-density lipoprotein, and low-density lipoprotein, were measured using enzymatic procedures and commercial kits. Daily milk yield was recorded and milk samples were collected at first, middle, and end of the experiment for analysis of milk composition using Milko Scan (model 130 series, type 10900 FOSS electric, Denmark). Body weight changes were individually determined biweekly before morning feeding. The growth of kids was also measured biweekly.

\section{Statistical analysis}

Analysis of variance (one-way, ANOVA) was performed to compare between different groups. Statistical analysis was carried out using SAS (2001) and Duncan's multiple range test (Duncan, 1955) was used to separate the means when the main effect was statistically significant at $\mathrm{p}<0.05$.

\section{RESULTS AND DISCUSSION}

The obtained results of Table 1 indicated that treating lemon pulp with yeast caused a decrease in dry matter, organic matter, ether extract, and nitrogen-free extract by $1.3 \%, 3.9 \%, 31.2 \%$, and $6.69 \%$, respectively. These decreases might be due to the internal metabolism and respiration of yeast, some amounts of carbon in lemon pulp are lost as carbon dioxide. Moreover, crude fiber content was a decrease by $20.1 \%$ after treatment and this may be due to the possible secretion of some extracellular enzymes, such as amylase and cellulose into the substrates which break the starch and other polysaccharides into simpler sugars easily metabolized by yeast as a source of carbon (Dadvaret al., 2015). However, there was an increase in crude protein $(\mathrm{CP})$ and ash content with that treatment by $56.4 \%$ and $40.3 \%$, respectively. These results were in agreement with the findings of Ezekiel et al. (2010) that there was an increase in ash content when cassava peels were fermented with Trichoderma viride. There was an increase in CP content since sugar could be an appropriate substrate for single-cell protein leading to the considerable final protein content of bioprocesses product $S$. cerevisiae. These results were in agreement with the findings of Roberta et al. (2007) who treated pineapple waste with $S$. cerevisiae leading to a significant increase in crude protein content of pineapple waste after processing. This increase can be attributed to high residual sugar as an appropriate substrate for single-cell protein leading to the considerable final 
protein content of bioprocesses product $S$. cerevisiae, which did not produce fungal toxins excreted by some filamentous fungi, such as aspergillus. Generally, yeasts have been shown to convert starchy materials, such as sweet potatoes and cassava peels, to protein. The increase in the ash content may not be a product of fermentation (Oboh, 2006).

Data in Table 2 represents the chemical composition of feedstuff and the similarity in chemical composition among the experimental diets used in the current experiment. The chemical composition of clover hay and concentrate feed mixture is in agreement with the findings of Sayed and Ghobashy (2018).

\section{Nutrients digestibility and feeding values}

Data in Table 3 showed that there was a significant increase in dry matter digestibility and NFE digestibility ( $\mathrm{p}<$ 0.05) when TLP feed in R2 or R3 was reported as (72.37 and 70.36\%) and (72.28 and 70.30\%), respectively, compared to $(70.99$ and $68.51 \%$ ) for R1. The same trend was observed for organic matter digestibility (OMD), crude protein digestibility (CPD), crude fiber digestibility (CFD), and ether extract digestibility (EED) with R3, compared to either R1 or R2. However, there were insignificant differences between R1 and R2 in OMD, CPD, and EED ( $p>0.05$ ) but CFD was significantly higher in R2 ( $\mathrm{p}<0.05)$, compared with R1.

These results might be due to the highly digestible NFE and high content of nonstructural carbohydrates of TLP diets, compared with control (Habeeb et al., 2017), or might be improving the rumen digestion environment with the TLP as mentioned by McDonald et al. (2011). This is due to yeast and its enzymes improving the rumen condition for fermentation. Miron et al. (2002) indicated that replacing 11\% dry citrus pulp with corn seeds resulted in better conditions for rumen microorganisms and improved the digestion of crude protein. Moreover, treated lemon pulp with $S$. cerevisiae increased the digestibility of crude protein leading to an increased crude protein in the rumen for microorganism utilization. Additionally, yeast caused an increase in fibrolytic bacteriain rumen (Habeeb et al., 2017). This positive effect for TLP might be due to replacing starchy concentrates with feeds rich in easily degradable cell walls had generally been associated with a more favorable rumen condition for cellulolytic bacteria (Arthington et al., 2002).

The results of nutrient digestibility were reflected on the nutritive value of the experimental diets where R3 recorded the highest significant total digestible nutrient (TDN) followed by R2 then R1 as 62.15\%, 60.98\%, and 59.35\%, respectively $(\mathrm{p}<0.05)$. However, there was an insignificant difference among groups regarding digestible crude protein (DCP) value ( $p>0.05)$. These results agreed with the finding of Kim et al. (2007) that citrus pulp supplementation might improve TDN and DCP.

Table 3. Digestion coefficients and nutritive values of the experimental Zaribi goats' diet

\begin{tabular}{|c|c|c|c|c|}
\hline \multirow{2}{*}{ Parameters } & \multicolumn{4}{|c|}{ Treatments } \\
\hline & R1 & $\mathbf{R 2}$ & R3 & SEM \\
\hline \multicolumn{5}{|c|}{ Digestibility coefficients (\%) } \\
\hline DM & $70.99^{\mathrm{b}}$ & $72.37^{\mathrm{a}}$ & $72.28^{\mathrm{a}}$ & 0.35 \\
\hline $\mathrm{OM}$ & $69.19^{\mathrm{b}}$ & $69.25^{\mathrm{b}}$ & $70.76^{\mathrm{a}}$ & 0.42 \\
\hline $\mathrm{CP}$ & $69.44^{\mathrm{b}}$ & $69.77^{\mathrm{b}}$ & $73.90^{\mathrm{a}}$ & 0.76 \\
\hline $\mathrm{CF}$ & $58.57^{\mathrm{c}}$ & $62.76^{\mathrm{b}}$ & $67.13^{\mathrm{a}}$ & 0.37 \\
\hline $\mathrm{EE}$ & $76.60^{\mathrm{b}}$ & $77.60^{\mathrm{b}}$ & $79.13^{\mathrm{a}}$ & 0.44 \\
\hline NFE & $68.51^{\mathrm{b}}$ & $70.36^{\mathrm{a}}$ & $70.30^{\mathrm{a}}$ & 0.37 \\
\hline \multicolumn{5}{|c|}{ Feeding values on DM basis (\%) } \\
\hline TDN & $59.35^{\mathrm{c}}$ & $60.98^{\mathrm{b}}$ & $62.15^{\mathrm{a}}$ & 0.44 \\
\hline DCP & 9.31 & 9.35 & 9.90 & 0.055 \\
\hline
\end{tabular}

\section{Milk yield and composition}

According to Table 4, milk yield significantly increased $(\mathrm{p}<0.05)$ by increasing the level of TLP in the diet as 1448.4 and $1558.7 \mathrm{~g} / \mathrm{h} / \mathrm{d}$ for R2 and R3, compared to $1377.6 \mathrm{~g} / \mathrm{h} / \mathrm{d}$ for R1. This increase might be due to the high TDN content in these diets, compared with the control diets (Schingoethe et al., 2004). Citrus pulp (dehydrated or ensiled) in diets for lactating ewes give conflicting results whereas some authors found no effect (Volanis et al., 2004), others reported a positive effect on daily milk yield (Piquer et al., 2011). Milk composition of T3 showed a significant increase in fat yield by $6.40 \%$, compared with control, this agrees with the finding of (Volanis et al., 2004) who found a significant increase in milk fat percentage in ewes fed ensiled citrus pulp attributed their results to the easily digestible fiber in citrus pulp silage, which modified condition in the rumen and improved microbial activity, which leads to fiber degradation and subsequent higher production of acetic acid (Piquer et al., 2009), and promotes milk fat synthesis in the mammary glands. 
Opposite results were seen by Piquer et al. (2011) when studied the effect of adding the citrus pulp to the diet of dairy ewes on the composition of milk. The results obtained by these authors showed that the use of $30 \%$ citrus pulp in the diet led to a reduction in milk fat content, while protein content was increased for ewes with $10 \%$ of citrus in the diets. The protein content of T3 had the highest value compared with control, this may result from supplementation of ruminant diets with citrus pulp may improve $\mathrm{N}$ utilization (Kim et al., 2007; Piquer et al., 2009), reducing the ruminal NH3-N escape, and consequently, the milk urea level, which several studies support this hypothesis in dairy ewes (Scatassa et al., 2006). Highly degradable carbohydrates led to the higher digestibility of the LP diets (Piquer et al., 2009), increased level of nitrogen absorption, and therefore, increased level of nitrogen excreted in milk. All treatments showed a significant increase in lactose and solid not fat, compared with control by increasing the level of TLP into the diets.

As can be seen in Table 5, there was a significant decrease between treatments in glucose concentration in the blood of goats fed LP this disagrees with the findings of Ali et al. (2016). Furthermore, blood serum cholesterol and TG levels decreased $(\mathrm{p}<0.05)$ in R2 and R3, compared with control, which disagrees with the findings of a study by Alnaimyet al. (2017) reporting that blood cholesterol concentration increased in cows fed with a diet containing dried citrus pulp. This decrease in cholesterol content might result from the prevention of cholesterol formation by Trippine in lemon pulp (Takarada et al., 2002).

Table 4. Effect of different experimental of Zaribi goats' diet on milk yield and its composition

\begin{tabular}{|c|c|c|c|c|}
\hline \multirow{2}{*}{ Parameters } & \multicolumn{4}{|c|}{ Treatments } \\
\hline & $\mathbf{R 1}$ & $\mathbf{R 2}$ & $\mathbf{R 3}$ & SEM \\
\hline Daily milk yield (g/h/d) & $1377.6^{\mathrm{c}}$ & $1448.4^{\mathrm{b}}$ & $1558.7^{\mathrm{a}}$ & \\
\hline Daily 4\%-FCM (g/h/d) & $1243.3^{c}$ & $1313.7^{\mathrm{b}}$ & $1359.9^{\mathrm{a}}$ & 2.48 \\
\hline \multicolumn{5}{|l|}{ Milk composition } \\
\hline Fat $(\%)$ & $3.35^{\mathrm{a}}$ & $3.38^{\mathrm{a}}$ & $3.15^{\mathrm{b}}$ & 0.14 \\
\hline Fat yield $(\mathrm{g})$ & $46.14^{\mathrm{b}}$ & $48.95^{\mathrm{a}}$ & $49.09^{\mathrm{a}}$ & 0.75 \\
\hline Protein $(\%)$ & 2.45 & 2.59 & 2.77 & 0.37 \\
\hline Protein yield (g) & $33.75^{\mathrm{c}}$ & $37.5^{\mathrm{b}}$ & $43.17^{\mathrm{a}}$ & 1.08 \\
\hline Lactose $(\%)$ & 3.94 & 3.45 & 3.44 & 0.54 \\
\hline Lactose yield (g) & $54.27^{\mathrm{c}}$ & $49.96^{\mathrm{b}}$ & $53.61^{\mathrm{a}}$ & 1.44 \\
\hline Total solids $(\%)$ & $10.5^{\mathrm{a}}$ & $10.31^{\mathrm{b}}$ & $10.29^{\mathrm{b}}$ & 0.78 \\
\hline Total solids yield (g) & $144.78^{c}$ & $149.33^{\mathrm{b}}$ & $160.39^{\mathrm{a}}$ & 1.84 \\
\hline Solids not fat $(\%)$ & 7.16 & 6.93 & 7.14 & 0.74 \\
\hline Solids not fat yield (g) & $98.63^{\mathrm{b}}$ & $100.37^{\mathrm{b}}$ & $111.29^{\mathrm{a}}$ & 1.71 \\
\hline Ash (\%) & 0.76 & 0.88 & 0.93 & 0.14 \\
\hline
\end{tabular}

Table 5. Biochemical parameters in blood serum of Zaribi goats as affected by feeding experimental diet

\begin{tabular}{lcccc}
\hline \multirow{2}{*}{ Parameters } & \multicolumn{3}{c}{ Treatments } \\
\cline { 2 - 5 } & R1 & R2 & R3 & SEM \\
\hline Tp (g/dl) & $6.45^{\mathrm{c}}$ & $7.33^{\mathrm{b}}$ & $7.84^{\mathrm{a}}$ & 0.92 \\
Alb (g/dl) & 3.94 & 3.97 & 4.17 & 2.38 \\
Glo (g/dl) & 2.51 & 3.36 & 3.67 & 3.77 \\
Ur (mg/dl) & 6.24 & 6.44 & 6.78 & 2.55 \\
Cr mg/dl & 1.14 & 1.12 & 0.17 \\
Glu (mg/dl) & $94.47^{\mathrm{a}}$ & $80.15^{\mathrm{b}}$ & $72.55^{\mathrm{c}}$ & 0.58 \\
ALT (U/L) & $15.74^{\mathrm{a}}$ & $14.33^{\mathrm{b}}$ & $14.77^{\mathrm{b}}$ & 0.13 \\
AST (U/L) & $26.79^{\mathrm{a}}$ & $24.16^{\mathrm{b}}$ & $22.48^{\mathrm{b}}$ & 0.91 \\
Cho (mg/dl) & $141.19^{\mathrm{a}}$ & $124.22^{\mathrm{b}}$ & $108.45^{\mathrm{c}}$ & 2.96 \\
HDL & $77.72^{\mathrm{a}}$ & $71.67^{\mathrm{b}}$ & $65.43^{\mathrm{c}}$ & 0.57 \\
LDL & $44.13^{\mathrm{a}}$ & $35.03^{\mathrm{b}}$ & $26.55^{\mathrm{c}}$ & 0.27 \\
TAC & $0.52^{\mathrm{b}}$ & $0.58^{\mathrm{ab}}$ & $0.85^{\mathrm{a}}$ & 0.24 \\
TG (mg/dl) & $96.71^{\mathrm{a}}$ & $87.56^{\mathrm{b}}$ & $82.35^{\mathrm{c}}$ & 1.68 \\
\hline
\end{tabular}

$\overline{\mathrm{a}, \mathrm{b}, \mathrm{c}}$ Means different superscripts in the same row are significantly different $(\mathrm{p}<0.05)$, TP: Total protein; Alb: Albumin, Glo: Globulin; Glu: Glucose, Cr: Creatinine, Ur: Urea-N Cho: Cholesterol, TG: Triglycerides, ALT: Alanine transaminase, AST: Aspartic transaminase, TAC: Total antioxidant capacity, SEM: Standard error mean, R1: Control diet (50\% concentrate feed mixture $+50 \%$ clover hay), R2: $37.5 \%$ concentrate feed mixture $+50 \%$ clover hay $+12.5 \%$ treated lemon pulp, R3: $25 \%$ concentrate feed mixture $+50 \%$ Clover hay $+25 \%$ treated lemon pulp 
Data showed that there were no significant $(\mathrm{p}<0.05)$ differences among groups in blood concentrations of albumin, globulin, urea, and creatinine. However, feed TLP in R2 and R3 significantly decreased blood concentration of glucose, ALT, AST, HDL and LDL ( $p<0.05)$, compared with control. Feeding dams on diets contained TLP improved total antioxidant capacity insignificantly for R2 $(\mathrm{p}>0.05)$ and significantly for $\mathrm{R} 3(\mathrm{p}<0.05)$ by $11.5 \%$ and $63.5 \%$, respectively, compared with control. These results agreed with the findings of Ali et al. (2016), while lemon increased the concentrations of high-density lipoprotein (HDL) increased, but the concentration of cholesterol and triglycerides declined. The increase in total antioxidant capacity with R2 and R3 might be due to the fact that lemon had a strong antioxidant activity of its essential oil on the removal of free radicals; this may be related to phenolic and flavonoids compounds (Ghasemi et al., 2009).

According to Table 5, blood total protein significantly increased linearly with the increasing TLP ( $\mathrm{p}<0.05$ ). These results are in agreement with those of Oni et al. (2008) that total plasma protein increased linearly with the increasing levels of citrus pulp. Table 6 shows the development of the body weight of kids and goats throughout the experimental period. Diets (R3) had a higher birth weight of kids, followed by those born from goats fed R2 diets, and less birth weight was obtained for goats in the control group (R1). This indicated that the diets improve the weight of the kids because the goat fed these diets at the last period of pregnancy.

Goats showed an increase in body weight after the parturition period in R3 followed by R2 indicating that an increase in digestion coefficient of TLP caused an increase in body weight for those groups. At the end of the experiment, kids in the group fed R3 showed the highest body weight and average daily gain, compared to the control (R1). This may be the result of an increase in milk yield so the kids had the best values of 280.3 and $226.3 \mathrm{~g} / \mathrm{day}$ for R3 and R2, respectively. Bueno et al. (2002) reported that different levels of orange pulp on Saanen kids' diets led to an increase in ADG, and kids fed a diet containing 42.3\% orange pulp had the highest value. This finding is in agreement with that of Castollo-Gonzalez (2014) who concluded that the ruminal microflora improved production. The reason is that ruminal microorganisms are very important for ruminant animals, so, it is necessary to increase information about microbial ecosystems to improve the rumination process. Therefore, using additives in ruminant diet improves the efficient nutrients digestibility and reduces the production cost.

Data in Table 8 indicates the prices of experimental materials and average daily feed intake. The results revealed that daily milk yield increased by $1558.7 \mathrm{~g} /$ dam/day for R3 which might result from replacing $50 \%$ pf CFM with TLP. This led to an increase in nutrient digestion, TDN, and modification of rumen fermentation which causes high improvement in milk yield. When comparing the total feed cost (LE/dam/day), it was found that R3 had the lowest price being 5.20 while the highest value was found in R1 being 5.63 LE. However, there was a decrease in feed cost $/ \mathrm{kg}$ milk by $18.38 \%$ and $7.10 \%$ for R3 and R2, compared with control, respectively. This represented that treatment LP with yeast could decrease the cost of production.

According to Table 7, feeding TLP in R2 and R3 respectively improved feed efficiency of DMI/FCM being 1.06 and 1.02 as well as DCPI/ FCM being 0.099 and 0.1 compared to 1.10 and 0.103 for R1.

Table 6. Effect of feeding different experimental diets on dams and their offspring performance

\begin{tabular}{|c|c|c|c|c|}
\hline \multirow{2}{*}{ Parameters } & \multicolumn{3}{|c|}{ Experimental diets } & \multirow{2}{*}{ SEM } \\
\hline & R1 & R2 & $\mathbf{R 3}$ & \\
\hline \multicolumn{5}{|l|}{ Dams performance } \\
\hline No. of dam kidded & 8 & 8 & 8 & - \\
\hline Initial weight at Late-pregnancy $(\mathrm{kg})$ & 34.22 & 33.88 & 34.15 & 3.75 \\
\hline Body weight at parturition $(\mathrm{kg})$ & 28.34 & 31.17 & 32.38 & 2.41 \\
\hline Body weight at 1 st month before parturition $(\mathrm{kg})$ & $22.49^{\mathrm{c}}$ & $24.88^{\mathrm{b}}$ & $26.33^{\mathrm{a}}$ & 0.17 \\
\hline Body weight two months before parturition $(\mathrm{kg})$ & 26.12 & 28.13 & 31.04 & 3.44 \\
\hline Body weight three months before parturition $(\mathrm{kg})$ & 29.71 & 31.85 & 32.79 & 2.18 \\
\hline \multicolumn{5}{|l|}{ Offspring performance } \\
\hline Total number of kids & 14 & 15 & 17 & - \\
\hline Litter size/ dam at birth & 1.75 & 1.87 & 2.12 & - \\
\hline Birth weight $(\mathrm{kg})$ & 2.63 & 2.48 & 2.35 & 0.47 \\
\hline weaning weight $(\mathrm{kg})$ & 13.44 & 13.37 & 14.25 & 2.48 \\
\hline Total weight gain $(\mathrm{kg})$ & 10.81 & 10.89 & 11.90 & - \\
\hline Average daily gain (g/ day) & $120.11^{\mathrm{b}}$ & $121.00^{\mathrm{b}}$ & $132.22^{\mathrm{a}}$ & 2.86 \\
\hline Relative improve (\%) & 100 & 100.7 & 110.1 & - \\
\hline \multicolumn{5}{|l|}{ Dam production } \\
\hline Litter weight at birth $(\mathrm{kg})$ & 4.60 & 4.63 & 4.98 & 2.46 \\
\hline Litter weight at weaning $(\mathrm{kg})$ & $23.52^{\mathrm{b}}$ & $25.00^{\mathrm{b}}$ & $30.21^{\mathrm{a}}$ & 1.67 \\
\hline Total litter weight gain $(\mathrm{kg})$ & 18.92 & 20.37 & 25.23 & - \\
\hline Average daily gain (g/day) & 210.2 & 226.3 & 280.3 & - \\
\hline
\end{tabular}

$\overline{\mathrm{a}, \mathrm{b}}$ Means different superscripts in the same row are significantly different (p < 0.05). SEM: Standard error mean, NO: Number, R1: Control diet (50\%concentrate feed mixture $+50 \%$ clover hay), R2: $37.5 \%$ concentrate feed mixture $+50 \%$ clover hay $+12.5 \%$ treated lemon pulp, R3: $25 \%$ concentrate feed mixture $+50 \%$ clover hay $+25 \%$ treated lemon pulp 
Table 7. Feed intake, milk yield, feed conversion, and feed efficiency of milk production of dams during the suckling period (90 days)

\begin{tabular}{lcccc}
\hline \multirow{2}{*}{ Parameters } & \multicolumn{3}{c}{ Experimental diets } & \multirow{2}{*}{ SEM } \\
\cline { 2 - 4 } & R1 & R2 & R3 & - \\
Total DM intake (g/ dam/day) & 1370 & 1390 & 1380 & - \\
TDNI (g/dam/day) & 813 & 848 & 858 & - \\
DCPI (g / dam /day) & 128 & 130 & 137 & 2.48 \\
Daily 4\%FCM (g/ dam/day) & $1243.3^{\mathrm{c}}$ & $1313.7^{\mathrm{b}}$ & $1359.9^{\mathrm{a}}$ & \\
\hline Feed conversion ratio & & & & \\
$\quad$ DM intake, g/g (4\% FCM) milk & 1.10 & 1.06 & - \\
TDNI, g/g (4\% FCM) milk & 0.65 & 0.65 & 0.63 & - \\
DCPI, g/g (4\% FCM) milk & 0.103 & 0.099 & 0.100 & - \\
\hline
\end{tabular}

$\overline{a, b, c}$ Means different superscripts in the same row are significantly different ( $<$ < 0.05). SEM: Standard Erro Mean, FCM: Fat corrected Milk, TDN: Total digestible nutrient, DCP: Digestible crude protein, TDNI: Total digestible nutrient intake, DCPI: Digestible crud protein intake

Table 8. Feed intake and economical evaluation of dams during the suckling period of 90 days

\begin{tabular}{|c|c|c|c|}
\hline \multirow{2}{*}{ Parameters } & \multicolumn{3}{|c|}{ Experimental diets } \\
\hline & $\mathbf{R 1}$ & $\mathbf{R 2}$ & $\mathbf{R 3}$ \\
\hline \multicolumn{4}{|l|}{ Average daily feed intake, g/dam/day (feed) } \\
\hline CFM & 712.5 & 550 & 347 \\
\hline Clover hay $(\mathrm{CH})$ & 818.75 & 830 & 848 \\
\hline Treated lemon pulp (TLP) & - & 180 & 365 \\
\hline Daily milk yield (g/ dam/day) & $1377.6^{c}$ & $1448.4^{\mathrm{b}}$ & $1558.7^{\mathrm{a}}$ \\
\hline \multicolumn{4}{|l|}{ Economical evaluation } \\
\hline \multicolumn{4}{|l|}{ Average total feed cost (LE/dam/day) } \\
\hline $\mathrm{CFM}$ & 3.34 & 2.58 & 1.63 \\
\hline Clover hay (BH) & 2.29 & 2.32 & 2.37 \\
\hline Treated lemon pulp (TLP) & - & 0.59 & 1.20 \\
\hline Total feed cost (LE/dam/day) & 5.63 & 5.49 & 5.20 \\
\hline Price of average daily milk (LE/dam/day) & 8.26 & 8.69 & 9.35 \\
\hline Feed cost (L.E) / milk (kg) & 4.08 & 3.79 & 3.33 \\
\hline
\end{tabular}

\section{CONCLUSION}

It could be concluded that replacement of concentrate feed mixture by lemon pulp treated by Saccharomyces cerevisiae in dairy goats diets can decrease the costs of feed and increase milk production by $50 \%$ without any adverse effect on milk yield, its composition, and animals health with high economic efficiency.

\section{DECLARATION}

\section{Authors' contributions}

Dr. Haiam A. Sayeddesigned the study, performed the chemical analysis and wrote the manuscript. Dr.Mouhmed M. Elmaghraby and Dr. Mohamed M. Elbadwy carried out the practical part of the experiment, collected samples from animals, and reviewed the manuscript. All authors read and approved the final manuscript

\section{Competing interests}

The authors declare that they have no competing interests.

\section{Acknowledgments}

To Dr. Helmey M. Yacout (professor of animal nutrition) for helping us to finish this work.

\section{Ethical considerations}

Ethical issues (including plagiarism, consent to publish, misconduct, data fabrication and/or falsification, double publication and/or submission, and redundancy) have been checked by the authors. 


\section{REFERENCES}

Ali M, Reza S, and Azadeh B (2016). Evaluation of antioxidant activity of citrus lemon L. essential oil and its effect on some blood parameters in Moghani sheep. Nutrition Science, 14(12): 108-113. DOI: https://www.doi.org/10.7537/marsnsj141216.17

Alnaimy A, Gad AE, Mustafa MM, Atta MA, and Basuony HA (2017). Using of citrus by-products in farm animals feeding. Open Access Journal of Science, 1(3): 58-67. DOI: https://www.doi.org/10.15406/oajs.2017.01.00014

Arthington JD, Kunkle WE, and Martin AM (2002). Citrus pulp for cattle. VeterinnaryClinics of North America Food Animal Protection, 18(2): 317326. DOI: https://www.doi.org/10.1016/s0749-0720(02)00023-3

Association of Official Analytical Chemists (AOAC) (1995). Official methods of analysis. 16th Ed. Washington DC, USA. Available at: https://www.worldcat.org/title/official-methods-of-analysis-of-aoac-international/oclc/421897987

Bueno MS, Ferrari JE, Bianchini D, Leinz FF, and Rodrigues CF (2002).Effect of replacing corn with dehydrated citrus pulp in diets of growing kids. Small Ruminant Research, 46: 179-185. DOI: https://www.doi.org/10.1016/S0921-4488(02)00184-0

Castollo-Gonzalez AR, Burrola-Barraza ME, Domingues-ViverosJ, and Chavez-Martineez A (2014). Rumen microorganism and fermentation.ArchvosMedicinaVeterinaria, 46: 349-361. DOI: http://www.dx.doi.org/10.4067/S0301-732X2014000300003

Crawshaw R (2004). Co-product feeds: Animal feeds from the food and drinks industries, Nothingham University Press. Available at: http://www.amazon.com/Co-Product-Feeds-Animal-Drinks-Industries/dp/1897676352

Dadvar P, Dayani O, Mehdipour M, and Morovat M (2015). Determination of physical characteristics, chemical composition and digestion coefficients of treated lemon pulp with Saccharomyces cerevisiae in goat diet. Journal of Animal Physiology and Animal Nutrition, 99:107-113. DOI: https://www.doi.org/10.1111/jpn.12204

Duncan DB (1955). Multiple ranges and multiple F test. Biometrics, 11:1-20. DOI: http://www.dx.doi.org/10.2307/3001478

Ezekiel OO, Aworh OC, Blaschek HP, and Ezeji TC (2010). Protein enrichment ofcassava peel by submerged fermentation with Trichodermaviride (ATCC 36316). African Journal of Biotechnology, 9(2): 187-194. Available at: https://www.ajol.info/index.php/ajb/article/view/77788

GhasemiK, Ghasemi Y, and Ebrahimzadeh MA (2009). Antioxidant activity, phenol and flavonoid contents of 13 Citrus species peels and tissues. Pakistan Journal of Pharmaceutical Science, 22(3): 277-281. Available at: https://pubmed.ncbi.nlm.nih.gov/19553174/

Grasser LA, Fadel JG, Garnett I, and De Peters EJ (1995). Quantity and economic importance of nine selected by-products used in California dairy rations. Journal of Dairy Science, 78: 962-971. Available at: https://www.doi.org/10.3168/jds.S0022-0302(95)76711-X

Habeeb AA, Gad AE, Mostafa MM, Atta AA, and Basuny AM (2017). Using of citrus by- products in farm animal feeding. Themed section: Science and Technolog, 3:2395-6011. Available at:https://www.academia.edu/34606849

Kim SC, Adesogan AT, and Arthington JD (2007). Optimizing nitrogen utilization in growing steers fed forage diets supplemented with dried citrus pulp. Journal of Animal Science, 85: 2548-2555. DOI: https://www.doi.org/10.2527/jas.2007-0059

McDonald P, Edwards RA, Greenhalgh JF, Morgan CA,Sinclair LA, and Wilkinson RG (2011). Animal nutrition. $7^{\text {th }}$ ed. Pearson, Harlow, UK: Prentice Hall/Pearson, p. 692. Available at:https://www.bookdepository.com/Animal-Nutrition-Peter-McDonald/9781408204238

Miron J, Yosef E, Ben- GhedaliD, Chase L, Bauman D, and Solomon R (2002). Digestibility by dairy cows of monosaccharaides constituents in total mixed rations containing citrus pulp. Journal of Dairy Science, 85: 89-94. DOI: https://www.doi.org/10.3168/jds.S0022-0302(02)74056-3

Oboh G (2006). Nutrient enrichment of cassava peels using Saccharomycescerevisae and Lactobacillus spp. solid media fermentation techniques. Electronic Journal of Biotechnology, 9:46-49. DOI: https://www.doi.org/10.2225/vol9-issue1-fulltext-1

Oni AO, Onwuka CF, Oduguwa OO, Onifade OS, and Arigbede OM (2008). Utilization of citrus pulp-based diets and Enterolobiumcyclocarpum(JACQ. GRISEB) foliage by West African dwarf goats. Livestock Science, 30: 184-91. DOI: https://www.doi.org/10.1016/j.livsci.2007.12.010

Pinto GA, Brito ES, Andrade AM, Fraga SL, and Teixeira RB (2005). Fermentação em estado sólido: Uma alternativa para o aproveitamento e valorização de resíduos agroindustriais tropicais. Comunicadotécnico Online, 102(1): 1-5. Available at: https://www.infoteca.cnptia.embrapa.br/bitstream/doc/426390/1/Ct102.pdf

Piquer O,Ródenas L, Casado C, Blas E, and Pascual JJ (2009). Whole citrus fruits as an alternative to wheat grain or citrus pulp in sheep diet: Effect on the evolution of ruminal parameters. Small Ruminant Research, 83: 14-21. DOI: https://www.doi.org/10.1016/j.smallrumres.2008.11.009

PiquerO, Ródenas L, Blasé, and Pascual JJ (2011). Whole citrus fruits in total mixed ration for Mediterranean milking ewes. Milk Production and Composition, pp. 251-258. Available at:https://riunet.upv.es/bitstream/handle/10251/147521

Roberta C, Margarida M, and Gorete M (2007). Protein enrichment of pineapple waste with saccharomyces cervisiae by solid state bioprocessing. Journal of Scientific and Industrial Research, 66: 259-262. Available at: http://nopr.niscair.res.in/handle/123456789/1239

Sayed HA, and Ghobashy H (2018). Effect of processing orange pulp with Saccharomyces cerevisiae yeast on growth performance, nutrients digestibility, and blood parameters of Barki lambs. Journal of Sheep and Goat Science, 13:33-45. DOI: https://www.doi.org/10.21608/EJSGS.2018.26301

Scatassa ML, TodaroM, Bruno S, and Giaccone P (2006). Le polpe fresche di limone nella dieta delle pecore da latte: Effetti sulla qualità del latte di massa (Fresh lemoncitrus pulp in dairy ewes feeding: Effects on tank milk quality). In: Proc. LX Congresso SIS Vetriney, Terrasini (PA), Italypp, pp. 515-516. Available at: https://refhub.elsevier.com/S0377-8401(16)30677-0/sbref0195

Scerra V, CaridiA, Foti F, and Sinatra MC (1999). Influence of dairy penicillium spp. on nutrient content of citrus fruit peel. Animal Feed Science and Technology, 78: 169-176. DOI: https://www.doi.org/10.1016/S0377-8401(98)00264-8

Schingoethe DJ, Linke KN, Kalscheur KF Hippen AR, Rennich DR, and Yoon I (2004). Feed efficiency of mid-lactation dairy cows fed yeast culture during summer. Journal of Dairy Science, 87: 4178-4181. DOI: https://www.doi.org/10.3168/jds.S0022-0302(04)73561-4

Statistical Analysis System (SAS) (2001). SAS user's guide statistics SAS Institute Inc. Editors, Cary, NC. Available at: https://support.sas.com/documentation/onlinedoc/91pdf/sasdoc_91/stat_ug 7313.pdf

Takarada K, Kimizuka R, Takahashi N, Honma K, Okuda K, and Kato T (2002). A comparison of the antibacterial efficacies of essential oils against oral pathogens. Oral Microbiology Immunology, 19: 61-64. DOI: https://www.doi.org/10.1046/j.0902-0055.2003.00111.x

Van-Keulen J, and Young BA (1977).Evaluation of acid-insoluble ash as neutral marker in ruminant digestibility studies. Journal of Animal Science, 44: 282-287. DOI: https://www.doi.org/10.3168/jds.2012-6442 
Vendruscolo F, Silva C, Esposito E, and Ninow JL (2009). Protein enrichment of apple pomace and use infeed for Nile Tilapia. Applied Biochemistry and Biotechnology, 152: 74-87. DOI: http://www.dx.doi.org/10.1007/s12010-008-8259-3

VolanisM, Zoiopoulos P, and Tzerakis K (2004). Effects of feeding ensiled sliced oranges to lactating dairy sheep. Small Ruminant Research, 53: 1521. DOI: http://www.dx.doi.org/10.1016/j.smallrumres.2003.07.011 